\title{
Konstruksi Kepemimpinanan Atas Tradisi Giri Kedaton Sebagai Identitas Sosial Budaya Masyarakat Kabupaten Gresik
}

\author{
Mustakim $^{1 *}$, Ishomuddin ${ }^{1}$, Wahyu Winarjo ${ }^{1}$, Khozin ${ }^{1}$ \\ 1 Program Studi Ilmu Sosial dan Ilmu Politik, Universitas Muhammadiyah Malang, Indonesia \\ *e-mail: mustakim_sejarah@yahoo.co.id
}

Article history: Received 05 February 2020; Accepted 11 April 2020; Available online 30 April 2020

\begin{abstract}
Abstrak
Penelitian ini bertujuan untuk mendeskrisikan konstruksi sosial pemimpin atas tradisi Giri Kedaton sebagai identitas sosial budaya masyarakat Kabupaten Gresik. Penelitian ini dilaksanakan di Kabupaten Gresik Jawa Timur dengan menggunakan paradigma interpretatif dan pendekatan kualitatif. Data diperoleh dari sumber primer dan sekunder. Teknik

Kata Kunci:

Konstruksi Pemimpin, Tradisi Giri Kedaton, Identitas Sosial Budaya pengumpulan data dilakukan melalui observasi nonpartisipan, wawancara, dan dokumentasi, dan teknik purposive sampling. Analisis data dilakukan melalui open coding, axial coding, dan selective coding, sedangkan analisis data melalui persistent observation, triangulation, member check and peer reviewing, dan referencial adequacy check. Hasil penelitian ini menunjukkan bahwa: identitas sosial sebagai realitas adalah ciptaan manusia kreatif melalui kekuatan konstuksi sosial di sekitarnya yang dikuatkan oleh hadirnya leader melalui regulasi pendukungnya. Proses penguatan identitas yang dilakukan melalui otoritas leader lebih efektif daripada pembentukan identitas oleh masyarakat. Konstruksi sosial atas realitas cenderung berlangsung melalui leader secara hirarkis-vertikal, bersifat spasial, yaitu berlangsung dari pimpinan kepada bawahannya. Berpijak dari teori konstruksi sosial atas realitas Peter L. Berger dan Luckman dengan melihat variabel leader menjadi sangat substansi dalam proses eksternalisasi, objektivasi, dan internalisasi, maka dapat dikatakan bahwa sifat dan kelebihan leader sebagai agen dalam proses eksternalisasi, objektivasi, dan internalisasi telah memperbaiki proses konstruksi sosial atau realitas yang berjalan lambat.
\end{abstract}

\section{Abstract}

The study aims to describe the social construction of the leader of the Giri Kedaton tradition as the socio-cultural identity of the Gresik Regency people. This research was conducted in Gresik Regency, East Java, using an interpretive paradigm and a qualitative approach. Data obtained from primary and secondary sources. Data collection techniques were carried out through non-participant observation, interviews, and documentation, and purposive sampling techniques. Data analysis was performed through open coding, axial coding, and selective coding, while data analysis was through persistent observation, triangulation, member checking, and peer-reviewing, and referential adequacy check. The results of this study indicate that social identity as reality is a creative human creation through the power of social construction around which is strengthened by the presence of a leader through supporting regulations. The process of strengthening the identity carried out through the authority of the leader is more effective than the formation of identity by the community. The social construction of reality tends to take place through leaders in a hierarchical-vertical, spatial manner; that is, it takes place from the leader to his subordinates. Based on the theory of social construction of the reality of Peter L. Berger and Luckman by seeing the leader variables become very substance in the process of externalization, objectivation and internalization, it can be said that the nature and strengths of leaders as agents in the externalization, objectivation, and internalization processes have improved the process of the slow social construction of reality.

Copyright (C) Universitas Pendidikan Ganesha. All rights reserved 


\section{Pendahuluan}

Beberapa tahun terakhir, perkembangan kota-kota di Indonesia semakin tidak jelas akan identitas dan karakternya kurang spesifik (Ali, 2009), sehingga terkesan mengabaikan sejarah masa lalunya. Selain itu, kota-kota di Indonesia juga banyak yang kehilangan jati diri atau identitas aslinya, akibat dari makin menjamurnya budaya instan di era globalisasi (Wikantyoso, 2007). Eksistensi kota-kota di Indonesia yang sebenarnya mendukung pertumbuhan nilai-nilai budaya lokal akhir-akhir ini terpengaruh dan tergeser oleh budaya asing. Padahal nilai-nilai budaya lokal itu pada gilirannya akan membentuk karakter dan identitas sebagai sebuah entitas bangsa. Aspek sejarah dan budaya lahirnya sebuah kota berangsur-angsur terabaikan oleh penguasa lokal dan masyarakatnya, sehingga kesinambungan budaya lokal seolah terputus akibat tata kelola yang tidak memperhatikan tatanan kehidupan dan aspek fungsi sebuah kawasan.

Di era otonomi daerah seperti sekarang ini, banyak kota yang berupaya untuk menemukan identitasnya. Terdapat banyak kabupaten yang merasa penting untuk merumuskan identitas sebagai pembeda antara kabupaten satu dengan lainnya. Identitas dijadikan sebagai sarana promosi untuk mencapai keunikan, keunggulan, dan prestasi, sehingga bisa bersaing dengan kabupaten/kota lainnya, maupun persaingan tingkat regional, nasional, dan internasional. Upaya menguatkan sebuah identitas yang kuat diperlukan berbagai kajian dan analisis yang mendalam dengan melihat peran pemerintah dan masyarakat. Secara umum sasaran identitas adalah mempromosikan potensi daerah sebagai daya tarik dibidang budaya, pariwisata, dan ekonomi.

Giri Kedaton sebagai sebuah kerajaan yang lahir tanggal 9 Maret 1487 M memiliki banyak tradisi yang sampai saat ini masih dilestarikan oleh masyarakat, seperti Malem Selawe, Rebo Wekasan, Kolak Ayam, Damar Kurung (Koeshandari, 2009), Kirab Budaya Giri Kedaton, Pasar Bandeng, dan Seni Macapat Gaya Gresikan (Luwar, 2008). Setiap tahun masyarakat Gresik mengadakan tradisi itu secara rutin, meskipun karena faktor tertentu ditiadakan. Akan tetapi tradisi itu muncul kembali pada kesempatan berikutnya. Tradisi Giri Kedaton rutin dilaksanakan oleh pemerintah dan masyarakat pendukung tradisi itu.

Keberadaan tradisi Giri Kedaton dengan berbagai ragam dan nilai budaya yang terkandung didalamnya itulah yang akan diteliti, dikaitkan teori konstruksi sosial atas realitas dari Berger \& Luckmann (1990). Keberadaan tradisi Giri Kedaton dengan berbagai macam nilai yang terkandung didalamnya itulah yang akan diidentifikasi. Identifikasi ini akan dikaitkan dengan konsep identitas dan teori konstruksi sosial. Karena itulah penelitian ini menggunakan pendekatan teoritik yang sesuai yaitu teori konstruksi social meliputi eksternalisasi, objektivasi, dan internalisasi, serta konsep identitas. Banyak kabupaten/kota yang memiliki pemahaman identitas yang kurang baik, indikasinya penerapan identitas masih dilaksanakan secara terpisah-pisah, misalnya hanya menggunakan logo atau slogan.

Identitas budaya dibangun dengan asumsi-asumsi persamaan dan perbedaan. Persamaanpersamaan suatu komunitas akan mengikat mereka dalam identitas tertentu sebagai satu kesatuan social dan budaya yang timbul secara unik (sebagai kami) atas dasar berbagai perbedaan dengan komunitas lain (sebagai mereka). Suatu masyarakat membangun identitas mereka atas dasar persamaan diantara anggota masyarakat itu sendiri sekaligus atas dasar perbedaannya dengan masyarakat lain. Karena itu, identitas budaya turut membangun kohesi dan solidaritas sosial dalam struktur internal masyarakat sesama pemilik identitas budaya. Setiap individu maupun komunitas akan membangun identitas dalam relasi sosial dan budaya untuk menegaskan posisi individual dan social suatu komunitas di hadapan komunitas lainnya. Identitas adalah representasi diri atau kelompok yang akan dilihat dan dinilai orang atau kelompok lain sebagai identitas social budaya (Hamidy, 2013).

Menurut teori interaksionisme simbolik, identitas adalah sebutan untuk mendefinisikan diri sendiri, dan biasanya sebutan tersebut diumumkan kepada orang lain sesuai dengan apa yang dilakukan untuk menunjukkan diri. Menurut Charon bahwa identitas adalah "the name we call ourselves, and usually it is the name we announce to others that we are as we act in situations". 
Interaksi simbolik menilai bahwa identitas adalah bagian dari konsep diri. Diri adalah sebuah objek yang ditunjukkan melalui perbuatan. Identitas adalah penamaan dari diri tersebut. Sama seperti objek-objek sosial lain bahwa identitas dibentuk, dipelihara, dan ditransformasi secara sosial (Berger, 1991). Seseorang mendefiniksan dirinya melalui interaksi dengan orang lain. Seperti halnya seorang memberikan label atau menami diri seseoranag, dengan begitu juga seseorang menami dirinya sendiri. Label yang diberikan itu menjadi sebutan untuk orang tersebut, menjadi alamat sosialnya, dan definisi mengenai dirinya dalam hubungan inetarksi seseorang dengan orang lain. Identitas adalah penamaan diri yang tidak tercipta oleh siapa saja secara sembarangan, melainkan adanya reference group dan significant others bagi orang tersebut (Charon, 1998). Peter Burke menyebutkan bahwa identities are meanings a person attribute to the self (Burke \& Jan, 1998).

Penelitian ini untuk mengkaji konstruksi pemimpin atas tradisi Giri Kedaton sebagai identitas sosial budaya masyarakat Kabupaten Gresik. Gresik membutuhkan banyak hal untuk mengenalkan dirinya sesuai dengan identitas yang dimiliki. Identitas Kabupaten Gresik secara terus menerus dicari hingga ditemukan yang paling menarik dan sesuai. Guna menelisik Tradisi Giri Kedaton sebagai proses penguatan identitas di Kabupaten Gresik, penelitian ini menggunakan teori kontruksi sosial yang dikembangkan oleh L. Berger bersama Thomas luckmann. Teori konstruksi sosial yang dikembangkan berpandangan bahwa realitas memiliki dimensi objektif dan subjektif. Manusia merupakan instrumen dalam menciptakan realitas yang objektif melalui proses eksternalisasi, sebagaimana ia mempengaruhinya melalui proses internalisasi yang menceminkan realitas yang subjektif. Jadi, masyarakat adalah produk manusia, manusia sebagai produk masyarakat, dan keduanya berlangsung secara dialektis (tesis, antitesis, dan sintetis). Kedialektisan itu sekaligus menandakan bahwa masyarakat tidak pernah sebagai produk akhir, tetapi sebagai proses yang sedang terbentuk dan berlangsung secara terus menerus (Hamidy, 2013). Manusia sebagai individu sosial tidak pernah stagnan (berdiam atau berhenti) selama ia hidup di tengah masyarakat.

Tesis utama Berger dan Luckman bahwa manusia dan masyarakat adalah produk yang dialektis, dinamis, dan plural secara terus menerus, ia bukan realitas tunggal yang statis dan final, melainkan merupakan realitas yang bersifat dinamis dan dialektis. Realitas bersifat plural ditandai dengan adanya relativitas seseorang ketika melihat kenyataan dan pengetahuan. Masyarakat adalah produk manusia, tetapi secara terus menerus mempunyai aksi kembali terhadap penghasilannya. Sebaliknya manusia juga produk masyarakat. Seseorang atau individu menjadi pribadi yang beridentitas kalau ia tetap tinggal dan menjadi entitas dari masyarakat.

Proses dialektis menurut Burger dan Luckmann, melingkupi tiga hal, yakni eksternalisasi, objektifikasi, dan internalisasi. Eksternalisasi merupakan ekspresi diri manusia ke dalam dunia luar, baik kegiatan mental maupun fisik dan itu bersifat kodrati manusia, karena selalu mencurahkan diri ke mana dia berada. Manusia ingin menemukan dirinya dalam satu dunia dalam suatu komunitas, sehingga perlu berproses dengan cara berinteraksi dengan lingkungan dan interaksi terus menerus, baik fisik maupun nonfisik hingga remaja, dewasa, tua, dan mati demi membentuk eksitensi diri (Berger, 1991). Berdasarkan latar belakang tersebut, maka dirumuskan masalah "Bagaimana konstruksi pemimpin atas tradisi Giri Kedaton sebagai identitas sosial budaya masyarakat Kabupaten Gresik?"

Jenkins menyebutkan bahwa identitas selalu melibatkan dua kriteria yaitu: perbandingan baik antara orang-orang ataupun hal-hal yang berhubungan dengan kesamaan dan perbedaan. Dilanjutkan Jenkins bahwa dalam ruang lingkup identitas sosial, maka ada dua subjek yang dijadikan pusat perhatian, yakni identitas sosial secara individu dan kolektif. Di sisi lain, identifikasi identitas kolektif adalah memunculkan citra kuat orang-orang yang dalam beberapa hal (subjek) tampaknya mirip satu sama lain. Dengan melibatkan aspek sosial dan psikologis, teori identitas sosial menyediakan piranti analisis bagi berbagai persoalan-persoalan yang terkait dengan fenomena-fenomena kehidupan kolektif, beserta berbagai dampak yang diakibatkan (Jenkins, 1996). 
Penelitian ini menggunakan teori identitas dari Castells (2001). Dalam salah satu triloginya yaitu "The Power of Identity" disebutkan bahwa keberadaan identitas akan bisa terbentuk hanya ketika ada internalisasi. Oleh karena itu asumsi yang dibangun oleh Castells, karena berangkatnya identitas ini dari internalisasi, yang mempengaruhi identitas adalah proses pemaknaan dari aturan yang telah ditetapkan oleh satu institusi. Konstruksi identitas sendiri dalam prosesnya sangat bergantung pada beberapa hal, diantaranya bersumber dari konteks sejarah, geografi, biologi, institusi produktif dan reproduktif, memori kolektif, fantasi personal, kekuasaan dan juga sisi-sisi keagamaan. Sehingga dalam era informasi (information age) seperti sekarang ini menurut Castells, tidak hanya akan melahirkan masyarakat jaringan (network societies) semata, tetapi juga turut mempengaruhi perubahan dalam berbagai bidang, termasuk di dalamnya bidang politik, budaya, ekonomi, dan juga kebudayaan.

Dalam menjelaskan proses konstruksi sosial atas identitas, Manuel Castells dalam The Power of Identity menuliskannya dalam tiga proposisi. Pertama, Legitimazing Identity, yang mana diperkenalkan oleh institusi yang dominan dalam satu masyarakat. Institusi inilah yang kemudian melakukan rasionalisasi atas identitas yang ingin mereka internalisasikan kepada anggota masyarakat melalui simpul aktor-aktornya. Kedua, Resistance Identity, yang mana terjadi ketika aktor-aktor merasa bahwa proses legitimizing identity mengalami penurunan nilai. Sehingga dengan kondisi yang demikian akhirnya membawa mereka untuk melakukan suatu tindakan oposisi atas proses legitimizing identity yang dilakukan oleh institusi dominan. Pada tahapan ini, lantas mereka akan mencoba untuk membangun pemakanaan baru akan identitas. Munculnya identitas baru ini yang lantas melahirkan adanya politik identitas dalam satu tatanan masyarakat. Ketiga, Project Identity, akan terjadi ketika aktor-aktor sosial berusaha untuk membangun identitas baru yang mendefiniskan mereka kembali dalam posisinya ditengah-tengah masyarakat dan selain itu juga berusaha untuk melakukan transformasi pada struktur sosial yang ada. Manuel Castells dalam proposisi yang ini mencontohkannya dengan gerakan-gerakan feminisime yang mengalami metamorfosis dari waktu ke waktu yaitu dengan adanya pendefinisian baru atas identitas yang melekat pada mereka (Castells, 2001).

Penelitian ini juga mengggunaan teori Kontruksi Sosial Berger dan Luckman. Dua istilah dalam sosiologi pengetahuan Berger adalah kenyataan dan pengetahuan. Berger dan Luckmann mulai menjelaskan realitas sosial dengan memisahkan pemahaman kenyataan dan pengetahuan. Realitas diartikan sebagai suatu kualitas yang terdapat didalam realitas-realitas yang diakui sebagai memiliki keberadaan (being) yang tidak tergantung pada kehendak kita sendiri. Sedangkan pengetahuan didefinisikan sebagai kepastian bahwa realitas-realitas itu nyata dan memiliki karakteristik yang spesifik (Berger \& Luckmann, 1990).

Kajian teori konstruksi memandang keberadaan suatu realitas sosial dilihat dari hasil konstruksi sosial dan kebenaran suatu realitas sosial bersifat nisbi, yang dapat dilihat dari tiga hal yang meliputi: Pertama dilihat dari penejelasan ontologism, realitas yang dikontruksikan itu berlaku sesuai kontek spesifik yang dinilai relevan oleh pelaku sosial. Kedua, ditinjau dari kontek epistemologis bahwa pemahaman tentang suatu realitas merupakan produk interaksi antara peneliti dan objek yang diteliti. Dalam hal ini teori kontruktivis bersifat transaksional atau subjektif. Ketiga dilihat dari kontek aksiologi, yaitu peneliti sebagai fasilititator yang menjembatani keragaman subjektivitas pelaku sosial (Hamidy, 2013).

Peta teori ilmu-ilmu sosial memasukkan teori konstruktivis ke dalam rumpun paradigma definisi sosial (Ritzer, 2001). Paradigma definisi sosial merupakan salah satu dari tiga paradigm dalam sosiologi. Dua paradigma lainnya adalah paradigma fakta sosial (klasik) dan paradigma perilaku sosial. Teori konstruktivis berada di dalam perspektif interpretative (penafsiran) yang memiliki tiga varian, yaitu interaksi simbolik, teori-teori fenomenologis, dan hermeneutic (Ritzer, 2009).

Landasan teori kontruksionis dipelopori oleh Petter L. Berger dan Tomas Lucman yang menulis karya dan menghasilkan tesis mengenai konstruksi sosial atas realitas (Eriyanto, 2004). 
Berger dan Luckmann menjelaskan bahwa teori konstruksi sosial berada diantara teori fakta sosial dan definisi sosial, dimana dalam teori fakta sosial, struktur sosial yang eksislah yang penting, manusia adalah produk dari masyarakat dan persepsi manusia ditentukan oleh struktur yang ada dalam masyarakat. Instititusional, norma, struktur dan lembaga sosial mempengaruhi perilaku invidu manusia. Menurut teori definisi sosial, manusia yang membentuk masyarakat, manusia digambarkan sebagai entitas yang otonom yang dapat melakukan pemaknaan dan membentuk masyarakat, sehingga yang membentuk realitas, menyusun institusi dan norma yang ada adalah manusia (Hamidy, 2013).

Berger dan Lukcmann menyakini secara subtansif bahwa realitas merupakan hasil ciptaan manusia yang kreatif melalui kekuatan kontruksi sosial terhadap dunia sosial di sekelilingnya. Pemikiran tersebut berakar pada konsep definisi sosial yang melihat teori sosial sebagai hasil konstruksi sosial yang diciptakan oleh individu sebagai manusia bebas, sehingga seorang individu menjadi sosok penentu dalam mengkontruksi dunia sosial yang dikehendakinya. Dalam banyak hal, manusia memiliki kebebasan dalam bertindak di luar batas pranata dan kontrol struktur sosial, yakni individu memaknai dunia sosialnya berupa respon-respon pada stimulus dalam dunia kognitifnya, sehingga dalam proses sosial, seorang individu dianggap tercipta dari realitas sosial yang relatif bebas di dalam dunia sosial (Hamidy, 2013).

Jika diamati, terdapat beberapa asumsi dasar dari teori konstruksi sosial menurut Berger dan Luckmann, yakni: realitas adalah produk ciptaan manusia yang kreatif melalui kekuatan konstuksi sosial terhadap lingkungan sosial sekelilingnya; hubungan antara pemikiran manusia dan kontek sosial bersifat berkembang dan dikembangkan; kehidupan dalam masyarakat sifatnya konstruksi terus menerus; antara realitas dan pengetahuan adalah dua hal yang berbeda, dimana realitas diartikan sebagai kualitas yang terdapat dalam kenyataan yang memiliki keberadaan (being) yang tidak bergantung kepada kehendak diri kita sendiri, sedangkan pengetahuan didefinisikan sebagai kepastian bahwa realitas itu nyata dan berkarakteristik (Hamidy, 2013). Menurut Berger dan Luckmann, institusi dalam masyarakat tercipta dan eksis karena tindakan manusia, sehingga meskipun masyarakat dan institusi sosial terlihat objektif, namun kenyataanya adalah dibangun secara subjektif melalui interaksi. Objektivitas muncul manakala terjadi penegasan berulang oleh orang lain yang memiliki definisi subjektif yang sama. Oleh karena itu pada tingkat generalisasi paling tinggi, manusia menciptakan dunia dalam makna simbolis yang universal yang memberi legitimasi dan mengatur bentuk-bentuk sosial serta memaknai pada berbagai ranah kehidupan.

Atas pengaruh Hegel tentang tesis-antitesis-sintesis, Berger menemukan konsep yang dapat menghubungkan antara yang subjektif dan objektif melalui tiga konsep dialektika: eksternalisasi adalah proses penyesuain diri denagan dunia sosio kultural sebagai produk manusia; objektivasi adalah proses interaksi sosial dalam dunia inter subjektif yang dilembagakan atau menagalami institusionalisasi; dan internalisasi adalaah proses dimana indvidu mengidentifikasi diri di tengah-tengah lembaga-lembaga sosial atau organisasi sosial yang dinaungi individu tersebut (Hamidy, 2013).

Proses dialektika domensi objektif dikaitkan dengan peran media dalam melihat realita akan menghasilkan dua hal, yakni kelembagaan dan legitimasi. Kemunculan lembaga dalam prespektif Berger terjadi ketika kegiatan manusia mengalami pembiasaan, yakni setiap tindakan yang sering diulangi menjadi suatu pola yang dapat direprodukasi dan dipahami oleh pelakunya sebagai pola yang dimaksud itu. Sementara itu legitimasi mengasilkan konsep baru yang berfungsi untuk mengintegrasikan makna-makna yang sudah diberikan pada proses kelembagaan yang berkelainan, sehingga pada akhirnya legitimasi dapat membuat objektivasi dan masuk akal secara subjektif (Hamidy, 2013).

Menurut Berger dan Luckmann, terdapat dua objek pokok realitas yang berkenaan dengan pengetahuan, yakni realitas subjektif dan realitas objektif. Realitas subjektif berupa pengetahuan individu. Disamping itu, realitas subjektif merupakan konstruksi definisi realitas yang dimiliki individu dan dikonstruksi melalui peoses intrnalisasi. Realitas subjektif yang dimilik masing-masing individu merupakan basis untuk melibatkan diri dalam proses 
eksternalisasi, atau proses interaksi sosial dengan individu lain dalam sebuah struktur sosial. Melalui proses eksternalisasi itulah individu secara kolektif berkemampuan melakukan objektivikasi dan memunculkan sebuah konstruksi realitas objektif yang baru (Polomo, 2010), sedangkan realitas objektif dimaknai sebagai fakta sosial. Disamping itu realitas objektif merupkan suatu kompleksitas definisi realitas serta rutinitas tindakan dan tingkah laku yang telah mapan terpola, yang kesemuanya dihayati oleh individu secara umum sebagai fakta.

Berger dan Luckmann mengatakan institusi masyarakat tercipta dan dipertahankan atau diubah melalui tindakan dan interaksi manusia. meskipun institusi sosial dan masyarakat terlihat nyata secara objektif, namun pada kenyataan semuanya dibangun dalam definisi subjektif melalui proses interaksi. Objektivitas baru bisa terjadi melalui penegasan berulangulang yang diberikan oleh orang lain yang memiliki definisi subjektif yang sama. Pada tingkat generalitas yang paling tinggi, manusia menciptakan dunia dalam makna simbolis yang universal, yaitu pandangan hidupnya yang menyeluruh, yang memberi legitimasi dan mengatur bentuk-bentuk sosial serta memberi makna pada berbagai bidang kehidupan. Pendek kata, Berger dan Luckmann mengatakan terjadi dialektika antara individu menciptakan masyarakat dan masyarakat menciptakan individu. Proses dialektika ini terjadi melalui eksternalisasi, objektivasi dan internalisasi (Bungin, 2008).

Teori konstruksi sosial dalam gagasan Berger mengandaikan bahwa agama sebagai bagian dari kebudayaan, merupakan konstruksi manusia. artinya terdapat proses dialektika ketika melihat hubungan masyarakat dengan agama, bahwa agama merupakan entitas yang objektif karena berada diluar diri manusia. dengan demikian agama, agama mengalami proses objektivasi, seperti ketika agama berada didalam teks atau menjadi tata nilai, norma, aturan dan sebagainya. Teks atau norma tersebut kemudian mengalami proses internalisasi kedalam diri individu, sebab agama telah diinterpretasikan oleh masyarakat untuk menjadi pedomannya. Agama juga mengalami proses eksternalisasi karena ia menjadi acuan norma dan tata nilai yang berfungsi menuntun dan mengontrol tindakan masyarakat (Berger \& Luckmann, 1990).

\section{Metode}

Penelitian tentang konstruksi sosial tradisi Giri Kedaton sebagai identitas sosial budaya masyarakat Kabupaten Gresik ini akan dikupas dengan paradigma interpretativisme. Paradigma ini dikenal juga dengan sebutan interaksionis subjektif (subjective interactionist). Interpretativisme adalah paradigma alternatif yang dimunculkan oleh para ahli filsafat dari Jerman yang menitikberatkan pada peranan bahasa, interpretasi, dan pemahaman dalam ilmu sosial. Basis pemikiran dalam paradigma ini yaitu kaidah-kaidah yang berlaku dalam ilmu alam (natural science) tidak dapat diterapkan pada ilmu-ilmu sosial (Sulistiyo, 2007).

Paradigma interpretativisme memandang bahwa realitas sosial secara sadar dan aktif dibangun sendiri oleh individu-individu, olek karena itu setiap individu mempunyai potensi untuk memberikan makna atas segala perbuatan yang dilakukan. Realitas sosial merupakan hasil bentukan dari serangkaian interaksi antar para pelaku sosial dalam sebuah lingkungan tertentu. Paradigma interpretaivisme juga melihat bahwa ilmu pengetahuan tidak digunakan untuk menjelaskan (to explain) dan memprediksi (to predict) sebagaimana halnya pada paradigma positivisme melainkan untuk memahami (to understand).

Terdapat tiga prinsip dasar yang menjadi landasan dalam pengembangan studi interpretatif. Tiga prinsip dasar tersebut adalah: 1) individu menyikapi sesuatu atau apa saja yang ada di lingkungannya berdasarkan makna sesuatu tersebut pada dirinya; 2) makna tersebut diberikan berdasarkan interaksi sosial yang dijalin dengan individu lain; dan 3) makna tersebut dipahami dan dimodifikasi oleh individu melalui proses interpretasi yang berkaitan dengan hal-hal lain yang dihadapinya.

Berdasarkan pada tiga prinsip dasar tersebut sebenarnya dapat dipahami lebih dalam bahwa terdapat asumsi penting yang menjadi latar belakang. Asumsi pertama bahwa individu dapat melihat dirinya sendiri sebagaimana ia melihat orang lain; kedua individu tidak dianggap pasif melainkan memiliki kemampuan secara aktif membaca situasi dan kondisi di sekitarnya. Oleh karena itu, kata kuncinya adalah bagaimana seorang individu dapat menafsirkan situasi 
yang dihadapinya sehingga suatu aktivitas sosial dikembangkan melalui pola-pola interaksi yang mendalam. Berdasarkan pada beberapa prinsip dasar tersebut maka paradigma interpretatif menekankan pada pemahaman makna melalui proses empati terhadap sesuatu aktivitas dan menempatkan suatu aktivitas yang ada dalam masyarakat sehingga dari satu aktivitas akan melahirkan banyak penafsiran dan analisis.

Pengungkapan tradisi Giri Kedaton sebagai identitas sosial budaya masyarakat Kabupaten Gresk dalam penelitian ini dilakukan melalui pendekatan kualitatif. Menurut Bogdan dan Tylor (L. Moleong, 2014) pendekatan kualitatif merupakan prosedur penelitian yang menghasilkan data deskriptif berupa narasi dari informan dan perilaku yang diamati. Penelitian kualitatif dilakukan pada kondisi alamiah dan bersifat penemuan. Peneliti merupakan instrumen kunci dalam penelitian kualitatif. Data yang dikumpulkan dinyatakan dalam bentuk kata-kata dan gambar, kata-kata disusun dalam kalimat, yaitu kalimat hasil wawancara antara peneliti dan informan.

Sementara itu Creswell mendefinsikan penelitian kualitatif sebagai proses penelitian yang mengeksplorasi masalah sosial dan manusia. Bagi Creswell dalam penelitian kualitatif, peneliti membangun gambaran yang komplek dan menyeluruh, menganalisis kata-kata, melaporkan secara detail pandangan responden dan melakukannya dalam sebuah setting penelitian yang naturalis (Creswell, 1998). Selain itu, Creswell juga mengatakan bahwa penelitian kualitatif berusaha menyediakan complex, holistic picture yang berarti penelitian kualitatif berusaha untuk membaca permasalahan dan segala kompleksitasnya. Karenanya, dibutuhkan banyak waktu dalam proses pengumpulan sampai dengan analisis data dalam penelitian kualitatif ini (Creswell, 2007).

Beberapa alasan dalam melakukan penelitian kualitatif menurut Creswell adalah; 1) jika pertanyaan penelitian adalah "apa" dan "bagaimana", 2) jika topik penelitian perlu dieksplorasi, maksudnya jika tidak terdapat teori yang menjelaskan secara detail permasalahan yang akan dikaji sehingga eksplorasi terhadap teori ini perlu dilakukan, 3) jika peneliti ingin meneliti manusia secara natural setting, 4) jika peneliti ingin meneliti dalam gaya literature narasi dan story editing, dan 5) jika peneliti berperan sebagai active learner yang melakukan penelitian karena ingin mempelajari sesuatu dan bukan mengujinya (Creswell, 1998).

Penelitian kualitatif ditujukan untuk mendapatkan sebuah pemahaman yang mendasar melalui sebuah pengalaman fisrt-hand dari peneliti yang langsung berproses dan melebur menjadi satu. Peneliti berbaur dan menjadi satu kesatuan yang tidak terpisahkan dengan subjek dan latar yang akan diteliti untuk memeroleh laporan yang sebenarnya, apa adanya, dan catatan-catatan lapangan yang aktual. Karena sifatnya yang merupakan fisrt-hand, maka dalam penelitian tentang tradisi Giri Kedaton sebagai identitas masyarakat Kabupaten Gresik ini harus terjun langsung dan harus mengenal langsung subjek yang menjadi sumber data penelitian. Pembatas antara peneliti dan subjek penelitian sedapat mungkin dihilangkan atau dilakukan sebuah minimalisasi sebagai upaya agar peneliti memahami sudut pandang dan perasaan subjek penelitian dengan optimal.

Suharsimi Arikunto mengatakan bahwa sumber data dalam penelitian adalah subjek di mana data dapat diperoleh (Arikunto, 1998). Sumber data dalam penelitian ini dibagi menjadi dua bagian, yaitu: sumber data primer (utama) dan sumber data sekeunder (penunjang). Sumber data primer adalah sumber data yang diperoleh secara langsung dari lapangan. Sumber primer berupa data yang diperoleh melalui sumber lisan maupun tulisan. Sedangkan sumber data sekunder adalah sumber data yang diambil dari literatur terkait dengan penelitian. Untuk mendapatkan data tersebut perlu ditentukan sumber data dengan baik, karena data tidak akan diperoleh tanpa adanya sumber data. Pemilihan dan penentuan jumlah sumber data tidak hanya didasarkan pada banyaknya informan, tetapi lebih dipentingkan pada pemenuhan kebutuhan data, sehingga sumber data di lapangan bisa berubah-ubah sesuai dengan kebutuhan.

Sumber data dalam penelitian ini dapat dibedakan menjadi dua, yaitu manusia (human) dan bukan manusia. Sumber data manusia berfungsi sebagai subjek atau informan kunci (key informan) dan data yang diperoleh melalui informan berupa soft data (data lunak), yang senantiasa dapat diperhalus, diperinci dan diperdalam, karena masih selalu dapat megalami 
perubahan. Sedangkan sumber data bukan manusia berupa dokumen yang relevan dengan fokus penelitian, seperti peristiwa atau aktivitas yang ada kaitannya dengan fokus penelitian. Data yang diperoleh melalui dokumen bersifat hard data (data keras), yakni data yang tidak mengalami perubahan lagi.

Perolehan data dalam penelitian ini dilakukan melalui instrumen pengumpul data. Sumber data dalam penelitian ini berasal dari person, place, dan paper. Perolehan data ini dilakukan secara holistik dan integratif, maka dalam penelitian ini digunakan teknik yang ditawarkan oleh Bogdan dan Biklen, yaitu: observasi nonpartisipan, wawancara mendalam, dan dokumentasi. Creswell (2007) menambahkan, yaitu: Audiovisual materials, sedangkan Robert K. Yin menyarankan enam teknik, antara lain: 1) dokumen (documentation); 2) rekaman arsip (archivalrecord); 3) wawancara (interview); 4) observasi langsung (direct observation); 5) observasi partisipan (participant observation); 6) perangkat fisik (physicalartifact).

Dalam analisis data didasarkan pada tema atau perspektif tertentu. Adapun langkahlangkah dalamm analisis data yang digunakan sebagai berikut: 1) Open Coding, yaitu membuat identifikasi, penamaan, kategori-kategori atas informasi yang diperoleh, dan penguaraian gejala yang ditemukan dalam teks. Adapun tahapan dalam Open Coding sebaga berikut: melakunan epoche atau bracketing for existence, selanjutnya melakukan observasi partisipasi, interview mendalam, reduksi data, penentuan kategorisasi, dan mengambil kategorisasi; 2) Axial Coding, yaitu memilih salah satu kategori dan menempatkannya dalam model teoritis dan melalui kombinasi cara berpikir induktif dan deduktif; dan 3) Selective Coding, yaitu merangkai sebuah cerita dari hubungan antar kategori atau memilih kategori inti dan menghubungkannya dengan kategori-kategori lain pada kategori inti (Dariyatno, 2009). Adapun implementasi selective coding adalah menjembatani antara data yang diperoleh dengan teori-teori yang digunakan dalam penelitian ini, dan temuan dalam penelitian ini disandingkan dengan temuan/teori penelitian terdahulu.

Untuk menjaga keabsahan temuan, dilakukan pengecekan keabsahan temuan melalui: a) perpanjangan kehadiran, b) observasi yang diperdalam (observasi lebih lanjut), c) triangulasi, merupakan teknik pemeriksaan keabsahan data yang memanfaatkan sesuatu yang lain di luar data itu sendiri untuk keperluan pengecekan atau sebagai pembanding terhadap data tersebut (Moleong, 2010). Triangulasi terdiri dari empat macam yakni : triangulasi dengan sumber, triangulasi dengan metode, triangulasi dengan peneliti lain, dan triangulasi dengan teori, d) audit trail mandiri, audit trail menjamin kebenaran penelitian dengan pemeriksaan terhadap data mentah (catatan lapangan), hasil analisis data, hasil sintesis data, dan catatan tentang proses yang digunakan seperti metodologi, desain dan sebagainya yang dilakukan oleh peneliti sendiri, dan e) pemeriksaan sejawat melalui diskusi.

\section{Hasil dan Pembahasan}

\section{Proses Eksternalisasi Pemimpin (Leader) atas Tradisi Giri Kedaton}

Eksternalisasi adalah penyesuaian diri dan pencurahan diri (Berger \& Luckmann, 1990) dengan dunia sosiokultural sebagai produk manusia. Manusia adalah produk masyarakat (society is a human product). Monen eksternalisasi sasi ini Bahasa dan tindakan merupakan dua sarana yang berperan dalam adaptasi denga sosiokulturalnya. Pada momen ini ditemukan dua bentuk adaptasi dan pencuraha yang dilakukan oleh individu terhadap dunia kultralnya, yaitu mereka menerima dunia tersebut, artinya mereka menyesuaikan tindakan mereka dengan dunianya, atau mereka melakukan penolakan terhadap dunia sosiokulturalnya itu.

Leader selaku tokoh-tokoh kunci melakukan adaptasi dan pencurahan dirinya terhadap situasi sosiokultural keagamaan masyarakat Gresik, baik secara fisik inderawi, mental intelektif, perseptif, refleksif, intuitif, deduktif, kontemplatif, spekulatif, praktis, dan sinergis (Berger dan Luckman, 1990). Adaptasi dan pencurajan itu dilakukan secara terus menerus.

Adaptasi dan pencurahan diri leader bersumber dari pengetahuan dan pemahamannya terhadap aturan-aturan agama, dan norma-norma yang ada dalam lingkungan masyarakatnya. Pemahamannya itu diimplementasikan dalam realitas kehidupan sosial masyarakat Gresik. Selanjutnya leader itu memposisikan pemahaman keagamaan dan norma-norma sosial dalam 
posisi utama sebagai insrumen pandangan hidup, dalam bertindak dan melakukan aktivitas sosial sehari-hari. Aktivitas itu memberikan manfaat bagi masyarakat dalam bidang spiritual, kultural, sosial politik, dan ekonomi.

Gresik sejak lama dikenal sebagai kota santri. Penamaan kota santri melekat pada situasi dimana pemahaman keagamaan masyarakat menjadi landasan utama dalam kehidupan masyarakatnya. Budaya masyarakat kota santri bagian dari penjelmaan dari pemahaman agama masyarakat yang dikuatkan oleh leader. Leader di sini diartikan sebagai leader dalam ruang politik pemerintahan dan leader dalam ruang sosiokultural.

Hadirnya leader dan penerimaan masyarakat Gresik terhadapnya merupakan buah dari kemampuannya dalam mengemas dan mengaplikan pemahamannya dengan menggunakan srategi yang santus, tegas, jelas, selektif, dan sinergis, dan sesuai dengan sosiokultural masyarakat Gresik. Ketertarikan masyarakat dan terpengaruhnya masyarakat bagian dari buah strategi yang dilakukan itu.

Tindakan-tindakan yang dilakukan oleh leader melalui pendekatan sosiokultural keagamaan. Pendekatan ini menjadi modal utama bagi leader untuk memahami kepentingan masyarakat, meskipun tanggapan pro dan kontra menjadi bagian penting yang tidak lepas dari proses interaksi sosial dengan masyarakatnya. Leader selalu menyadari bahwa berbagai masalah yang muncul yang mengahadang leader didasari pada kurangnya pemahaman masyarakat terhadap realitas yang sesungguhnya. Ekternalisasi leader terhadap masyarakat Kabupaten Gresik meliputi aspek spiritual, kultural, politik, dan ekonomi.

Kenyataan hidup sehari-hari bersifat intersubjektif, dipahami bersama-sama oleh orang yang hidup dalam masyarakat sebagai kenyataan yang dialami. Meskipun kenyataan hidup sehari-hari merupakan dunia intersubjektif tetapi bukan berarti antara orang yang satu dengan lainnya selalu memiliki kesamaan perspektif dalam memandang dunia bersama. Setiap orang memiliki perspektif yang berbeda-beda dalam memandang dunia bersama yang bersifat intersubjektif. Perspektif orang yang satu dengan lainnya tidak hanya berbeda tetapi sangat mungkin juga bertentangan. Tetapi, terdapat persesuaian yang berlangsung terus menerus antara makna orang yang satu dengan lainnya. Hal ini menunjukkan bahwa terdapat dialektika dimana antitesa dan sintesa selalu terjadi dalam ruang sosial. Dialektika sebagai proses dialog diri subjektif dengan dunia luarnya melahirkan keselarasan, pertentangan, dan perdamaian.

Berikutnya terdapat kesadaran bersama mengenai kenyataan didalamnya menuju sikap alamiah atau sikap kesadaran akal sehat. Sikap ini kemudian mengacu pada suatu dunia yang secara bersama dialami oleh banyak orang. Jika hal ini sudah terjadi maka dapat disebut dengan pengetahuan akal sehat (common-sense knowledge), yakni pengetahuan yang dimiliki semua orang dalam kegiatan rutin yang normal dan sudah jelas dengan sendirinya dalam kehidupan sehari-hari. Pada tahap ini masing-masing individu melakukan eksternalisasi dalam kehidupannya, termasuk leader (pemerintah, organisasi masyarakat, tokoh masyarakat, dan LSM) sebagai agen dalam memahami atau menafsirkan relaitasnya.

Eksternalisasi dilakukan oleh masyarakat dipertegas oleh leader sebagai agen, artinya seorang leader ikut hadir dalam proses eksternalisasi. Kehadiran leader dalam tradisi ini dimulai dari pencurahan yang dilakukan sebagai pembawa amanat rakyat dan diwujudkan dalam bentuk peraturan-peraturan, baik itu Peraturan Daerah, Peraturan Bupati, Instruksi Bupati, program kerja, maupun dukungan fisik dan nonfisik. Proses ini berlangsung terus menerus ke dalam dunia sosial masyarakat Gresik, baik dalam aktivitas fisik maupun mentalitasnya. Selanjutnya masyarakat Gresik memiliki karakteristik sendiri. Secara geografis masyarakat Gresik memiliki akses ekonomi, budaya, dan pendidikan yang sudah maju dibandingkan beberapa daerah lain di sekitarnya, seperti Lamongan, Tuban, Bojonegoro, Sidoarjo, dan Mojokerto. Kemajuan akses itu tidak terlepas dari posisi geografis Gresik yang memiliki pelabuhan dagang. Pelabuhan ini mampu menunjukkan dinamika kehidupan masyarakatnya. Keadaan masyarakat Gresik yang sudah berkembang pesat ini merupakan pengalaman bagi leader sebagai agen yang bisa dijadikan sebagai dasar untuk membentuk pengetahuan atau mengkonstruksi sesuatu ke dalam dirinya. 
Gresik sebagai daerah yang memiliki keunggulan dibandingkan dengan daerah lain di sekitarnya memberikan dampak bagi kehidupan budaya masyarakatnya. Keunggulan ekonomi masyarakat Gresik seringkali berdampak pada melemahnya kehidupan budaya. Hadirnya leader sebagai agen dalam menangani masalah tradisi merupakan upaya untuk mengurangi masalah lunturnya tradisi di tengah globalisasi. Realitas sosial masyarakat Gresik mengharuskan leader untuk memberikan respon.

Sesuai paparan di atas, bahwa proses eksternalisasi dapat dipahami sebagai upaya pencurahan atau ungkapan ekspresi diri manusia (masyarakat) secara terus menerus ke dalam dunia yang ditempati, baik dalam aspek mental maupun fisik. Tentunya ini sudah menjadi sifat dasar manusia. Manusia pada dasarnya selalu ingin berekspresi untuk menunjukkan keberadaannya di dalam masyarakat. Manusia berupaya untuk menangkap dirinya dan dalam proses inilah dihasilkan suatu dunia menurt persepsinya. Manusia berupaya menemukan dirinya sendiri dalam proses dunia ini. Manusia butuh berekspresi dan berkarya untuk mengungkapkan jatidirinya, menunjukkan eksistensi atau keberadaannya, dan sebagai upaya mencurahkan hasil cipta, rasa, dan karsanya.

Upaya manusia untuk menunjukkan eksistensi jati dirinya tentu sejalan dengan hakikat mansuia sebagai makhluk sosial dan juga sebagai makhluk individu yang membutuhkan orang lain dalam segala aspek hidup di dunia. Dalam berekspresi atau proses eksternalisasi ini dapat dilihat dalam bentuk segala aktivitas harian, tingkah laku, bahasa, tradisi-tradisi, tindakantindakan yang muncul didasarkan atas penafsiran subjektif. Namun demikian, aktivitas yang nampak tersebut bukanlah hal yang tanpa sengaja atau spontan terjadi begitu saja. Segala tindakan atau eksternalisasi yang ditampilkan tersebut merupakan sebuah pengambilan keputusan yang dimaknai secara mendalam bagi manusia tersebut. Manusia memikirkan, memilih, dan menentukan tindakan apa atau tindakan yang bagaimana berakibat bahwa proses ekternalisasi tersebut dilakukan di dalam masyarakat.

Dalam hal ini sebagai realitasnya adalah keberadaan tradisi Giri Kedaton. Masyarakat di Kabupaten Gresik mencurahkan pengetahuannya terkait dengan tradisi Giri Kedaton. Pencurahan pengetahuan terkait tradisi Giri Kedaton diwujudkan dalam kegiatan turut serta dalam perayaan tradisi-tradisi tersebut dengan dilandasi beberapa alasan logis, sebagai bagian dari upaya menunjukkan ekspresi jati diri sebagai masyarakat setempat yang berbudaya. Masyarakat Gresik menyelenggarakan tradisi Giri Kedaton dalam rangka mengungkapkan eksistensi sebagai masyarakat yang diakui. Proses pelaksanaan tradisi Giri Kedaton merujuk pada acuan pembiasaan (habitualisasi) yang telah terlegitimasi oleh dirinya sendiri serta masyarakat sekitarnya. Proses ini berlangsung secara berkelanjutan dari generasi ke generasi berikutnya sepanjang masa selama ratusan tahun (Lestari, Setiawan, \& Puspitaningrum, 2018).

Beragam tradisi Giri Kedaton yang dilakukan oleh masyarakat mengacu pada ajaran agama (Islam) yang dianut masyarakat setempat, sehingga dengan demikian tidak dianggap sebagai sesuatu yang menyimpang oleh masyarakat secara ajaran agama (syirik), atau bertentangan dengan norma-norma masyarakat Gresik yang berlaku pada umumnya. Maknanya, tradisi Giri Kedaton yang ada di Gresik adalah produk kreativitas dari mereka sendiri, masyarakat berdasarkan ajaran-ajaran agama yang dianutnya. Termasuk sebenarnya masyarakatpun adalah bagian dari produk manusia yang ada. Fenomena demikian ini oleh Berger dan Luckman disebut dengan konsep ekternalisasi.

Realitas atau kenyataan merupakan hasil ciptaan manusia kreatif melalui konstruksi sosial terhadap dunia sosial di sekelilingnya. Masyarakat dalam pamndangan Berger dan Luckman (1990) merupakan suatu kenyataan objektif yang didalamnya terdapat proses pelembagaan yang dibangun dengan pembiasaan (habitualisation). Apabila habitualisasi atau pembiasaan ini terus berlangsung, maka akan terjadi pengendapan dan menjadi suatu tradisi. Berdasarkan analisis data di lapangan di peroleh empat domain konstruksi sosial masyarakat yang diperkuat oleh peran leader terhadap tradisi Giri Kedaton, yaitu spiritual, kultural, ekonomi, dan politik.

Adapun eksternalisasi yang dilakukan oleh leader dalam membangun tradisi Giri Kedaton sebagai identitas masyarakat Gresik, antara lain: Pertama, eksternalisasi terhadap sosiokultural 
keagamaan dalam tradisi Giri Kedaton. Kehadiran leader dalam perencanaan dan pelaksanaan (melalui produk regulasi) dapat mempertegas keberadaan tradisi Giri Kedaton dalam kehidupan sosiokultural keagamaan masyarakat Gresik. Kedua, Kehadiran penguasa dalam tradisi Giri Kedaton dapat diterima oleh masyarakat, karena kemampuan leader dalam mengemas proses pelibatan masyarakat dalam penyusunan regulasi dan penerapannya, baik berupa Peraturan Daerah, Peraturan Bupati, maupun Instruksi Bupati, dan program kerja terkait dengan pelestarian budaya lokal Gresik, termasuk didalamya Tradisi Giri Kedaton. Ketiga, leader sebagai agen sosial mampu mengeksternalisasikan dirinya pada masyarakat melalui peningkatan kualitas regulasi dan program dalam mendukung pelaksanaan Tradisi Giri Kedaton.

\section{Proses Objektivasi Pemimpin (Leader) atas Tradisi Giri Kedaton}

Objektivasi dapat diartikan sebagai suatu hasil yang telah dicapai, baik mental maupun fisik dari kegiatan ekternalisasi manusia. Hasil eksternalisasi menghasilkan sebuah realitas objektif yang dapat dilihat secara nyata. Hasil dari ekternalisasi ini dapat berupa kebudayaan atau tradisi-tradisi yang banyak berkembang di masyarakat sekitar. Misalnya dapat dilihat dengan adanya perkembangan tradisi Giri Kedaton di berbagai daerah di Gresik. Dalam konteks sederhana, bahwa proses ekternalisasi tersebut menghasilkan suatu alat yang dibutuhkan oleh manusia untuk mendukung proses hidupnya sehari-hari, ataupun ragam bahasa sebagai bentuk budaya. Apapun yang dihasilkan, baik alat atau benda serta bahasa itulah yang dinamakan realitas objektif sebagai wujud produk dari aktivitas manusia.

Proses objektivasi terjadi ketika sebuah produk dari aktivitas sosial tersebut telah membentuk suatu fakta (faktisitas) yang bersifat eksternal dan bersifat lain dari pembuatnya sendiri. Momentum inilah yang mengungkapkan adanya suatu dimensi inter-subjektif yang dilembagakan berhasil menuju kepada hasil fiktif atau mental yang dicapai dari beberapa momen ekternalisasi yang seolah-olah menjadi suatu hal yang berdiri sendiri (otonom) dan berhadapan dengan orang-perorang, menjadi fakta di luar. Hal ini menjadi sesuatu yang berbeda dengan yang menciptakannya (manusia sebagai pencipta fakta) .

Dalam pelaksanaan tradisi Giri Kedaton, proses objektivasi sendiri muncul sebagai hal yang otonom di luar manusia. Beragam tradisi menjadi produk dari aktivitas manusia sebagai pendukung kebudayaan-kebudayaan yang berkembang di Gresik. Dengan demikian, tradisitradisi seperti; Malem Selawe, Rebo Wekasan, Kolak Ayam, Damar Kurung, Kirab Budaya Giri Kedaton, Pasar Bandeng, serta Seni Macapat Gaya Gresikan merupakan produk manusia yang ada di Gresik. Hal ini karena tradisi-tradisi tersebut menjadi sebuah tardisi umum yang mampu melintasi ruang dan waktu. Tradisi Giri Kedaton tidak hanya berlaku di kawasan Giri saja, namun sudah menjadi model atau simbol dari kebudayaan masyarakat di Gresik secara umum.

Proses objektivasi ini tampaknya didukung pula oleh leader, seperti pemangku kepentingan atau Pemerintah Kabupaten Gresik dengan menyediakan regulasi, sarana dan prasarana sebagai pendukung pelaksanaan kegiatan tradisi Giri Kedaton. Pemerintah melalui dinas terkait bahkan menjadi pihak yang gencar dalam rangka mensosialisasikan tradisi-tradisi budaya Giri Kedaton dalam beberapa kesempatan, selain masyarakat itu sendiri di dalamnya.

Dalam tahap objektivasi ini, masyarakat Gresik sebagai realitas objektif menyiratkan pelembagaan di dalamnya. Proses pelembagaan (institusionalisasi) diawali dengan eksternalisasi berulang-ulang yang dilakukan oleh leader sebagai agen yang mempertegas eksternalisasi yang dilakukan oleh masyarakat, sehingga terlihat polanya dan dapat dipahami bersama yang menghasilkan pembiasaan (habitualisasi). Habitualisasi yang berlangsung lama akan mengalami pengendapan dan menjadi sebuah tradisi yang kuat dalam kehidupan sosiokultural masyarakat.

Pengendapan dan tradisi ini kemudian diwariskan secara estafet pada generasi berikutnya melalui regulasi dan penerapannya. Disinilah terlihat peranan agen/actor dalam tatanan kelembagaan, termasuk dalam membiasakan pengalaman dan proses pewarisan pengalaman tersebut. Peranan leader sebagai actor/agen sosial adalah represetasi dari unsur pemerintah dan swasta sebagai pembawa amanat rakyat. 
Peranan leader merepresentasikan suatu keseluruhan rangkaian perilaku yang melembaga. Leader berperan sebagai leading sector yang hadir dalam area sosialkultural keagamaan. Dalam konteks ini leader bukan sebagai agen utama, melainkan sebagai penguat dan penegas melalui produk regulasi dan program dalam pelestarian Tradisi Giri Kedaton. Masyarakat sebagai realitas objektif juga menyiratkan keterlibatan legitimasi. Legitimasi merupakan objektivasi makna pada tingkat kedua, dan merupakan pengetahuan yang berdimensi kognitif dan normatif karena tidak hanya menyangkut penjelasan tetapi juga nilainilai. Legitimasi bertujuan untuk membuat objektivasi yang sudah melembaga menjadi masuk akal secara subjektif. Dalam kontek ini diperlukan sebuah universum simbolik yang menyediakan legitimasi utama keteraturan pelembagaan. Universum simbolik menduduki hirarki yang tinggi, mentahbiskan bahwa semua realitas adalah bermakna bagi individu, dan individu melakukan sesuai dengan makna itu. Agar individu memahami makna itu, maka diperlukan organisasi sosial sebagai pemelihara universum simbolik.

Objektivasi yang dilakukan oleh leader adalah proses mengkristalkan keadaan pikiran tentang suatu objek, atau segala bentuk eksternalisasi yang dilakukan dilihat kembali dalam kenyataan di lingkungan secara objektif yaitu masyarakat pendukung tradisi pada lingkup dimana tradisi itu eksis secara khusus dan masyarakat Gresik secara umum. Dalam konteks ini leader melakukan pemaknaan baru ataupun pemaknaan tambahan. Proses objektivasi merupakan momen interaksi antara dua realitas yang terpisahkan satu sama lainnya, leader di satu sisi dan realitas sosiokultural masyarakat dimana tradisi itu dilestarikan secara khusus dan masyaraat Gresik umumnya. Kedua entitas yang seolah terpisah ini kemudian membentuk jaringan interaksi intersubjektif. Momentum ini merupakan hasil dari kenyataan eksternalisasi yang kemudian beraktualisasi sebagai suatu kenyataan yang unik.

Secara umum tradisi Giri Kedaton sebagai local wisdom dapat dipahami sebagai gagasangagasan setempat (lokal) yang bersifat bijaksana, penuh kearifan, bernilai baik, yang tertanam dan diikuti oleh masyarakatnya. Kesadaran masyarakat Gresik bahwa mereka hidup di wilayah yang secara historis merupakan awal Islam di Nusantara membentuk sebuah kosntruksi sosial terhadap tradisi yang muncul dari masa Kerajaan Giri Kedaton. Konstruksi sosial itu kemudian diaplikasikan dalam berbagai macam bentuk ritual tradisi dan bahkan mitos yang memiliki dimensi sebagai suatu kearifan lokal.

Dimensi-dimensi kearifan lokal itu telah menjadi tradisi yang turun menurun dan hidup dalam masyarakat. Dimensi kearifan lokal itu terwujud dalam bentuk ide-ide, gagasan yang dimplementasikan dalam bentuk tindakan dan prilaku yang meninggalkan jejak dalam kehidupan sehari-hari masyarakat Gresik. Sebagaimana telah dikemukanan bahwa masyarakat dalam pandangan Berger dan Luckman (1990) adalah suatu realitas objektif yang didalamnya terdapat proses pelembagaan yang dibangun denga pembiasaan (habitualisation) yang semakin lama akan mengendap menjadi tradisi. Meminjam istilah Berger dan Luckman tersebut, masyarakat sebagai tempat individu saling berinteraksi dan bersosialisasi sebagai suatu kenyataan objektif, maka didalamnya terdapat suatu proses habitualisasi dengan cara membangun atau merekosntruksi pola-pola interaksi dan sosialisasi dalam bentuk mitos, tradisi, dan kearifan lokal.

Berger memandang realitas sosial bergerak dalam tiga proses utama, yakni eksternalisasi, objektivasi, berbalik membentuk manusia melalui mekanisme internalisasi. Realitas sosial yang pada dasarnya melalui proses internalisasi. Dalam proses adaptasi diranah sosial dengan mengacu pada regulasi sebagai penegas pelaksanaan tradisi, kemudian proses eksternalisasi menjelma pada realitas yang objektif dari leader. Proses objektivasi itu terealisasi dalam institusi, antara lain sebagai berikut.

Pertama, terinstitusionalisasi dan terlegitimasi pada aspek spiritual sebagai objektivasi dari leader yang berorientasi pada pengembangan spiritual masyarakat Gresik yang berkualitas. Secara konseptual objektivasi tersebut menjiwai rumusan visi, misi, dan program pemerintah, maupun lembaga-lembaga pengembang tradisi. Kebetulan Wakil Bupati Gresik adalah seorang agamawan, sehingga objektivasi pada aspek spiritual sangat terlihat. Adapun pemerintah dan lembaga yang dimaksud antara lain; Pemerintah Kabupaten Gresik (Dinas Kebudayaan dan 
Pariwisata, Dinas Pendidikan), serta lembaga lainnya yang memiliki konsentrasi dibidang sejarah dan budaya, seperti Mataseger (Masyarakat Pecinta Sejarah Gresik), Besali Gresik, Gresik Heritage, Damar Kurung Institute, LSBO Pimpinan Daerah Muhammadiyah, Gresik Movie, Masyarakat Sejarawan Indonesia (MSI), serta lembaga-lembaga pendidikan formal maupun nonformal. Kedua, objektivasi juga diejawantahkan leader pada dimensi kultural. Kepedulian penguasa pada aspek kultural tidak lepas dari tokoh sentral Pemerintah Kabupaten Gresik merupakan pribadi yang mencitai budaya lokal, sehingga adaptasi dirinya yang diikuti oleh para bawahannya telah melahirkan objektivasi pada kepedulian kultural berupa kegiatan masyarakat Gresik yang peduli pada tradisi Giri Kedaton. Kepedulian ini diwujudkan dalam kegiatan rutin tradisi Giri Kedaton setiap tahunnya. Ketiga, objektivasi yang diejawantahkan oleh leader pada aspek peningkatan ekonomi kerakyatan. Objektivasi ekonomi tersebut tidak jauh dari realitas masyarakat yang memerlukan ruang pengembangan ekonomi, mengingat secara kultural Gresik juga disebut sebagai kota saudagar. Bupati Gresik sebagai leader dilingkup pemerintah adalah seorang pengusaha, sehingga program pemerintah terkait pengembangan ekonomi kerakyatan dalam momen tradisi ini sangat berpihak pada penduduk lokal. Sebelumnya ruang penjualan bebas disewa oleh masyarakat umum, baik Gresik maupun luar Gresik, namun pada saat ini disediakan untuk para pedagang Gresik sendiri. Keempat, objektivasi yang diejawantahkan oleh leader pada aspek politik. Objektivasi politik terikat pada kepentingan-kepentingan leader atas eksistensi dirinya dalam lingkup sosial masyarakatnya. Legitimasi kekuasaan dimanapun sangat penting dilakukan oleh leader. Legitimasi ini sebagai upaya agar leader diakui dan dihormati oleh rakyatnya. Hadirnya leader di tengah-tengah aktivtas tradisi Giri Kedaton memiliki nilai tinggi untuk mendekatkan diri pada masyarakatnya. Leader adalah produk masyarakat, dan sebaliknya masyarakat adalah produk dari leader.

\section{Proses Internalisasi Pemimpin (Leader) atas Tradisi Giri Kedaton}

Proses internaliasasi merupakan peyerapan kembali dunia objektif ke dalam kesadaran sedemikian rupa sehingga unsur-unsur subjektif individu tersebut dipengaruhi oleh strukturstruktur dunia sosial. Beragam unsur yang telah menjadi hal objektif ditangkap sebagai gejala realitas sosial diluar kesadaran manusia, serta sebagai gejala internal bagi kesadaran. Melalui proses internalisasi, manusia menjadi hasil dari masyarakat. Menurut Berger, realitas itu tidak dibentuk secara ilmiah, tidak juga sesuatu yang diturunkan oleh Tuhan. Tetapi realitas sosial itu dibentuk dan dikonstruksi oleh manusia. Maknanya, dengan pemahaman yang sedemikian ini, realitas sosial dapat berwajah ganda/plural. Setiap orang dapat memiliki konstruksi yang berbeda-beda atas apa yang dilihatnya, apa yang dimaknainya terhadap sebuah realitas yang ada di dalam masyarakat sekitar. Hal ini karena setiap orang dalam proses merekonstruksi fenomena tersebut didasari oleh pengalaman yang telah dimiliki, preferensi, kepentingan, tingkat pendidikan, dan kondisi lingkungan sosial budaya pergaulan pertemanan atau kondisikondisi sosial tertentu sebagai latar belakang tingkat daya penafsiran realitas sosial sesuai dengan bagaimana cara dan hasil konstruksi sosialnya masing-masing.

Proses penting dalam aspek internalisasi ini dapat dilihat pada segi sosialisasi. Sosialiasi dalam rangka pengalihan makna-makna yang terobjektivasi dari satu generasi ke generasi berikutnya melalui proses belajar atau aktivitas tradisi kebudayaan yang ada dalam tradisitradisi Giri Kedaton. Sosialisasi menjadi sarana bagi pewarisan beragam tradisi dan budaya antara para pendahulu dengan generasi berikutnya. Hal ini sengaja dilakukan agar tradisi-tradisi yang telah tercipta tidak terputus, serta dapat terus berlangsung serta lestari bagi keberlangsungan masyarakat setempat.

Dalam proses sosialisasi ini dibutuhkan atau dijumpai orang-orang yang berpengaruh untuk menjabarakan makna-makna tradisi kepada masyarakat berikutnya. Orang berpengaruh tersebut adalah leader yng bisa berasal dari tokoh pemerintahan, tokoh adat, pemuka agama, atau orang-orang terpilih yang begitu dipercaya oleh masyarakat dalam rangka upaya sosialisasi tradisi Giri Kedaton. Orang tersebut sebagai perantara dalam pelestarian tradisi Giri Kedaton. Orang tersebut menjadi salah satu acuan bagi norma pelaksanaan tradisi Giri Kedaton. Di dalam 
masyarakat, posisi leader atau elit ini dibutuhkan bagi kelangsungan tradisi-tardisi Giri Kedaton yang dimaksud.

Dalam proses internalisasi ini, masyarakat perlu menyesuaikan dengan acuan-acuan yang telah disepakati oleh para pendahulu agar merasa tidak terkucil dan tersendiri. Masyarakat perlu menyelaraskan hal-hal yang detail sebagai salah satu bentuk acuan pelaksanaan tradisi Giri Kedaton. Acuan tersebut merupakan kesepahaman nilai-nilai yang dihormati, dijalankan, dan ditaati dalam setiap pelaksanaan tradisi Giri Kedaton. Norma dan nilai-nilai menjadi hal yang dijunjung tinggi dalam pelaksanaan tardisi di Gresik. Dengan adanya acuan norma yang terinternalisasi baik formal maupun nonformal akan terwujud keselarasan tradisi Giri Kedaton di dalam masyarakat sepanjang masa. Adanya keselarasan yang dipakai sebagai acuan, maka tradisi Giri Kedaton dapat berangsung selama ratusan tahun lamanya di wilayah Gresik. Kepatuhan masyarakat terhadap nilai-nilai dan norma-norma tradisi inilah yang menjadi hal penting dalam pelaksanaannya.

Internalisasi yang berlangsung dalam masyarakat (manusia) bukan menujukkan kondisi aspek atau peran yang pasif bagi manusia itu sendiri, namun justru hal ini menunjukkan tingkat keaktifan manusia sebagai pendukung masyarakat dan kebudayaan yang ada di wilayah Gresik. Dalam hal ini, manusia bukan hanya sebagai sebagai objek relitas sosial, melainkan sebagai subjek yang aktif dalam proses internalisasi dan sosialisasi tradisi kebudayaan yang ada pada pelaksanaan tradisi Giri Kedaton di berbagai daerah. Masing-masing individu secara aktif bersosialisasi dalam proses internalisasi, mempelajari budaya, menggali makna, menyusun persepsi, dan ikut terlibat didalam aktivitas-aktivitas kebudayaan yang ada. Mereka mengidentifikasikan dirinya masing-masing dalam unsur-unsur tradisi budaya itu sendiri, menyelami dan mendalami praktik-praktik tradisi kebudayaan yang berkembang. Masyarakat menjadi manusia yang hidup dalam aktivitas budaya dan tardisi Giri Kedaton di berbagai wilayah Gresik dan sekitarnya.

Kenyataan sosial merupakan bagian dari konstruksi sosial masyarakat yang berlangsung cukup lama. Dalam hal ini Berger menyatakan bahwa konstruksi sosial memberikan pencerahan terhadap pemahaman makna sebuah realitas sosial. Dunia manusia ditandai dengan keterbukaan dan perilakunya. Manusia secara sadar dalam bertindak dan memaknai beragam lingkungan sekitarnya melalui proses yang diungkapkan oleh Berger. Proses tersebut melalui tahapan atau konsep ekternalsasi, objektivasi, dan internalisasi. Ketiga komponen tersebut memberikan landasan dan pemahaman bagaimana realitas sosial dibentuk oleh masyarakat, termasuk realitas sosial tradisi Giri Kedaton yang ada di Gresik.

Dalam kajian penelitian ini menunjukkan bahwa tradisi Giri Kedaton yang terdiri atas tujuh unsur tradisi, yaitu Malem Selawe, Rebo Wekasan, Kolak Ayam, Damar Kurung, Kirab Budaya Giri Kedaton, Pasar Bandeng, serta Seni Macapat Gaya Gresikan merupakan sebuah realitas sosial masyarakat yang dikonstruksi sejak lama, yaitu sejak berdirinya kerajaan Giri Kedaton. Kebesaran kerajaan Giri Kedaton telah memberikan andil besar bagi perkembangan tradisi budaya yang ada di dalam masyarakat Gresik dan sekitarnya. Giri Kedaton sebagai pusat atau sumber budaya yang melahirnkan budaya-budaya baru yang sampai saat ini masih dilestarikan oleh masyarakat.

Nilai-nilai budaya yang ada pada tradisi Giri Kedaton pada dasarnya bersumber pada nilainilai ajaran agama yang telah berkembang sejak era Walisongo abad ke 15-16 M, khususnya masa Sunan Giri yang ada di Gresik. Tradisi Giri Kedaton memberikan gambaran bagaimana hubungan masyarakat dengan Sang Pencipta secara religius dan spiritualitas. Dalam hal ini, tradisi menjadi sarana dalam mendekatkan diri masyarakat kepada Tuhan. Tradisi Giri Kedaton menajdi jembatan penghubung batin dan sebagai ekspresi (eksternalisasi) rasa syukur atas karunia yang diberikan oleh Tuhan kepada masyarakat Gresik.

Sebagai bagian dari aspek spiritualitas masyarakat Gresik, tradisi Giri Kedaton yang meliputi segi Malem Selawe, Rebo Wekasan, Kolak Ayam, Damar Kurung, Kirab Budaya Giri Kedaton, Pasar Bandeng, serta Seni Macapat Gaya Gresikan juga berkaitan erat dalam aspek sosial budaya, serta ekonomi masyarakat. Tradisi Giri Kedaton dengan beraneka ragam budayanya menjadi magnet tersendiri bagi masyarakat dalam mengembangkan aspek ekonomi 
dengan pengemasan budaya yang menarik dan kekinian. Pengemasan tradisi budaya yang menarik ini tentunya tanpa meninggalkan nilai-nilai pokok budaya yang terkandung di dalamnya, atau pesan moral yang terkandung di dalam setiap tradisi Giri Kedaton masingmasing. Artinya, dalam hal ini masyarakat benar-benar mampu memanfaatkan perkembangan tradisi Giri Kedaton tidak hanya sebagai sarana religius semata namun juga sebagai pengembangan aspek sosial, budaya, dan ekonomi masyarakat.

Proses sosialisasi tradisi budaya Giri Kedaton menjadi jalan untuk melestarikan budaya ini. Proses sosialisasi juga dikenal dalam kajian teori konstruksi sosial Berger, dimana dalam hal ini dibutuhkan sosok orang-orang berpengaruh untuk menjelaskannya. Orang yang dipandang layak menjalankan peran sosialisasi tradisi budaya meliputi penguasa politik/pemerintah, budayawan, para elit, sesepuh, tokoh adat, pemuka agama, dan orang yang memahami betul unsur-unsur budaya Giri Kedaton. Mengingat dalam tradisi Giri Kedaton terdapat tujuh unsur budaya, yang meliputi Malem Selawe, Rebo Wekasan, Kolak Ayam, Damar Kurung, Kirab Budaya Giri Kedaton, Pasar Bandeng, serta Seni Macapat Gaya Gresikan, maka dalam proses sosialisasi juga akan didapati beragam orang berpengaruh yang mampu menjelaskan aspek-aspek tradisi di dalamnya.

Dalam proses sosialisasi tersebut, tidak hanya aspek spiritual tradisi semata, namun juga aspek spolitik, budaya, dan ekonomi turut disosialisasikan. Semua aspek menyatu dalam sebuah tardisi Giri Kedaton sebagai khazanah kekayaan lokal yang ada di Gresik. Kekayaan lokal inilah yang kemudian dijadikan identitas sosial masyarakat Gresik. Melalui pengenalan tradisi-tradisi Giri Kedaton maka juga mampu mengangkat citra masyarakat Gresik. Kekayan budaya Giri Kedaton telah melekat pada masyarakat Gresik, di sisi lain, keberadaan budaya tersebut juga merupakan kekayaan lokal bagi Gresik. Dari sini, tradisi budaya Giri Kedaton mampu menjadi identitas Gresik, mengingat terus dilestarikan dan dipertahankan nilai-nilainya oleh masyarakat setempat.

\section{Temuan Teori dan Proposisi}

Berdasarkan sajian data, analisis hasil penelitian, dan temuan penelitian, maka dapat dibangun sebuah teori yaitu Leader Construction of Local Culture Identity Theory (Teori Konstruksi Pemimpin atas Identitas Budaya Lokal). Asumsi dasar teori ini bahwa identitas sosial sebagai realitas adalah ciptaan manusia kreatif melalui kekuatan konstuksi sosial di sekitarnya yang dikuatkan oleh hadirnya leader melalui regulasi pendukungnya. Proses penguatan identitas yang dilakukan melalui otoritas leader lebih efektif daripada pembentukan identitas oleh masyarakat. Konstruksi sosial atas realitas cenderung berlangsung melalui leader secara hirarkis-vertikal, bersifat spasial, yaitu berlangsung dari pimpinan kepada bawahannya, pimpinan kepada massanya, kiai kepada santrinya, guru kepada muridnya, orangtua kepada anak-anaknya, dan sebagainya.

Berpijak dari teori konstruksi sosial atas realitas Peter L. Berger dan Luckman dengan melihat variabel leader menjadi sangat substansi dalam proses eksternalisasi, objektivasi, dan internalisasi, maka dapat dikatakan bahwa sifat dan kelebihan leader sebagai agen dalam proses eksternalisasi, objektivasi, dan internalisasi telah memperbaiki proses konstruksi sosial atau realitas yang berjalan lambat itu. Leader Construction of Local Tradition Culture Identity Theory adalah pada sirkulasi pewarisan tradisi yang cepat dan merata dalam spasial tertentu.

Proposisi-proposisi dari teori Leader Construction of Local Culture Identity Theory dirumuskan sebagai berikut: 1) Proses membangun identitas sosial budaya lokal oleh pemimpin (leader) akan berjalan denngan baik, jika melalui adaptasi dan pencurahan diri terhadap sosiokultural baik dalam aktivitas fisik maupun nonfisik (mental); 2) Proses membangun identitas sosial budaya lokal oleh pemimpin (leader) akan berjalan baik, jika diawali dengan kesadaran individu untuk melakukan adaptasi diri dengan sosiokultural tradisional, baik dengan membangun kesadaran masyarakat, terlembagakan, maupun terlegitimasikan dalam perayaan tradisi yang selalu dijunjung tinggi sepanjang masa; dan 3) Proses membangun identitas sosial budaya lokal oleh pemimpin (leader) akan berjalan baik, jika melalui regulasi yang dibuat dan mengawalnya dalam pelaksanaan di lapangan sosiokultural. 


\section{Simpulan dan Saran}

Dalam bab hasil dan pembahasan telah dipaparkan hasil kajian terkait dengan tradisi Giri Kedaton sebagai identitas sosial budaya masyarakat Kabupaten Gresik menggunakan teori identitas (Manuel Castells) dan konstruksi sosial atas realitas (Peter L. Berger dan Thomas Luckman). Berdasarkan analisis data yang dilakukan, maka dapat disimpulkan:

Pertama; Tokoh-tokoh kunci (leader) dalam ekternalisasi telah melakukan adaptasi diri dan mengaktualisasikan stock of knowledge yang dimilikinya terhadap sosiokultural keagamaan masyarakat Kabupaten Gresik secara totalitas dengan memposisikan pengetahuan sosiokultural keagamaan dalam posisi sentral dan sebagai instrumen hidupnya.

Kedua; Dalam objektivasi, tokoh-tokoh kunci (leader) dengan pemahaman sosiokultural keagamaan yang dimilikinya yang telah diwujudkan dalam bentuk regulasi, program kerja, dan berbagai bentuk dukungan yang dilakukan mampu menguatkan tradisi budaya Giri Kedaton dalam kehidupan masyarakat Kabupaten Gresik. Penguatan tujuh tradisi Giri Kedaton itu mengarah pada empat kebutuhan, yaitu spiritual, kultural, politik, dan ekonomi. Tujuh tradisi itu sangat mengakar dan menjadi identitas dalam kehidupan masyarakat Kabupaten Gresik.

Ketiga; Dalam internalisasi, leader sebagai bagian dari makhluk sosial bersikap terbuka dan tidak membatasi interaksi dirinya dengan dunia sosiokultural keagamaan dengan masyarakat di sekitarnya. Leader melakukan interaksi sosial dengan seluruh lapisan masyarakat Kabupaten Gresik. Hasil interaksi itu terwujud menjadi karakter masyarakat Kabupaten Gresik yang menerima dan memahami tradisi Giri Kedaton sebagai bagian dari tradisi dalam kehidupan masyarakat dan dilaksanakan setiap tahun. Sosialisasi merupakan aspek penting dalam internalisasi. Sosialiasi dalam rangka pengalihan makna-makna yang terobjektivasi dari satu generasi ke generasi berikutnya melalui proses belajar atau aktivitas tradisi kebudayaan yang ada dalam tradisi-tradisi Giri Kedaton. Sosialisasi menjadi sarana bagi pewarisan beragam tradisi dan budaya antara para pendahulu dengan generasi berikutnya. Hal ini sengaja dilakukan agar tradisi-tradisi yang telah tercipta tidak terputus, serta dapat terus berlangsung serta lestari bagi keberlangsungan masyarakat setempat.

Tradisi Giri Kedaton yang berkembang dan secara rutin diselenggarakan oleh masyarakat dan Pemerintah Kabupaten Gresik mengandung nilai-nilai yang positif, yaitu nilai budaya, agama, ekonomi, social, dan politik. Masyarakat Kabupaten Gresik yang multikultural tidak lepas dari latar belakang sejarahnya sebagai kota bandar dagang ternyata mampu menjaga keberagaman itu. Keberagaman menjadi sebuah kekuatan berdasarkan nilai-nilai luhur yang bisa diambil dari penyelenggaraan tradisi Giri Kedaton. Pengetahuan yang diperoleh dari nilainilai identitas (Manuel Castells) dan konstruksi sosial (Berger dan Luckman) sangat berguna bagi masyarakat Kabupaten Gresik dalam kehidupan sehari-hari. Tradisi Giri Kedaton tidak lagi hanya memiliki makna kultural dan spiritual, tetapi sudah berkembang ke makna, ekonomi, bahkan politik.

\section{Daftar Pustaka}

Ali, A. A. (2009). Identitas Kota, Fenomena dan Permsalahannya. Jurnal Ruang, 1(1).

Arikunto, S. (1998). Prosedur Penelitian Suatu Pendekatan Pratik. Jakarta: Rineka Cipta.

Berger, P. L. (1991). Langit Suci: Agama Sebagai Realitas Sosial. Jakarta: LP3ES.

Berger, P. L., \& Luckmann, T. (1990). Tafsir Sosial atas Kenyataan. Jakarta: LP3ES.

Bungin, B. (2008). Konstruksi Sosial Media Massa:Kekuatan Pengaruh Media Massa, Iklan Televisi dan Keputusan Konsumen serta Kritik Terhadap Peter L. Berger dan Thomas Luckmann. Jakarta: Kencana.

Burke, J. P., \& Jan, S. E. (1998). Identity Theory And Social Identity Theory. Washington DC: Washington State University.

Castells, M. (2001). The Power of Identity The Information Age : Economy, Society and Culture. The Power of Identity, 2.

Charon, J. M. (1998). Symbolic Interactionism: an Introduction, an Interpretation, an Integration, 
Edition 6. New Jersey: Prentice Hall International, Inc.

Creswell, J. W. (1998). Qualitative Inquiry and Research Design, Choosing Among Five Traditions. California: SAGE Publications.

Creswell, J. W. (2007). Reseach Design; Pendekatan Kualitatif, Kuantitatif, dan Mixed. Yogyakarta: Pustaka Pelajar.

Dariyatno, T. (2009). Handbook of Qualitative Research. (Denzin \& Y. S. Lincoln, Eds.). Yogyakarta: Pustaka Pelajar.

Eriyanto. (2004). Analisis Framing. Yogyakarta: LKiS.

Hamidy, F. (2013). Tabot Sebagai Identitas Masyarakat Kota Bengkulu Menurut Perspektif Bergerian. Universitas Airlangga.

Jenkins, R. (1996). Social Identity. London: Routledge Taylor and Francis Group.

Koeshandari, I. I. (2009). Damar Kurung dari Masa ke Masa. Surabaya: Dewan Kesenian Jawa Timur.

Lestari, P., Setiawan, A., \& Puspitaningrum, A. (2018). Urgensi Habituasi Nilai Karakter Kemandirian Dan Tanggung Jawab Peserta Didik Sekolah Menengah Keguruan. Jurnal Ilmiah Ilmu Sosial, 4(2), 114-119.

Luwar. (2008). No TitleMacapat Gaya Gresik: Narasumber Bapak Mat Kauli Sebagai Bahan Pembelajaran Tingkat SMA, SMK dan Masyarakat. Surabaya: Karunia.

Moleong, L. (2014). Metode Penelitian Kualitatif. Bandung: Remaja Rosdakarya.

Moleong, L. J. (2010). Metodologi Penelitian Kualitatif. Bandung: PT Remaja.

Ritzer, G. (2001). Sociological Theory (Fifth). University Of Maryland.

Ritzer, G. (2009). Teori Sosiologi: Dari Teori Sosiologi Klasik Sampai Perkembangan Mutakhir Teori Sosial Postmodern. Yogyakarta: Kreasi Wacana.

Sulistiyo, A. B. (2007). Memahami Paradigma Interpretivisme, Kritisisme Dan Postmodernisme Dalam Penelitian Sosial Dan Akuntansi. Retrieved March 28, 2019, from file://localhost/h:/non POS/Agung Budi Sulistiyo.htm

Wikantyoso, R. (2007). Perencanaan dan Perancangan Kota Malang: Kajian Historis Kota Malang, Arsitektur Indis. Retrieved January 13, 2019, from http.mintakat.unmer.ac.id./edisi/4 